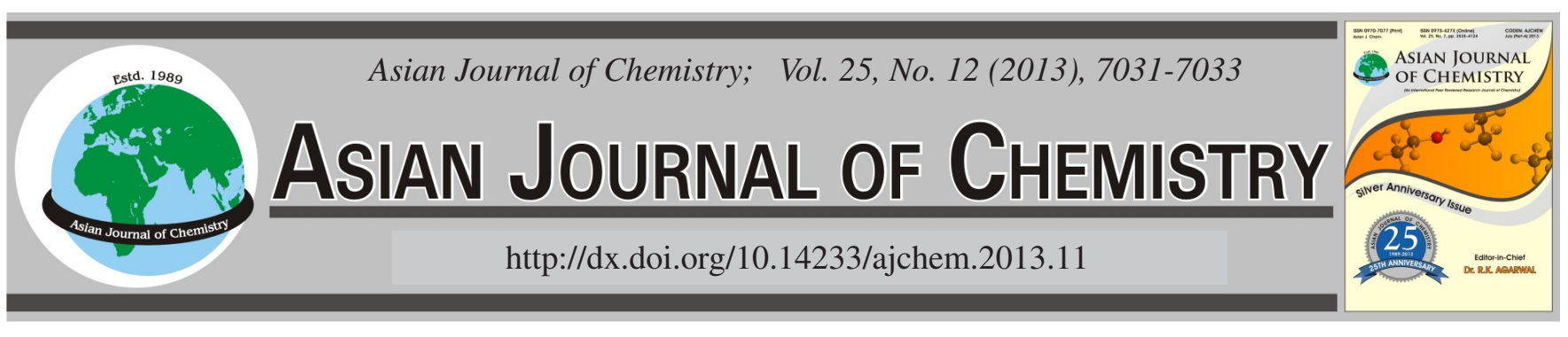

\title{
Simultaneous Determination of Caesium, Neodymium, Uranium and Plutonium Isotopes in Pressurized Water Reactor Spent Nuclear Fuels by Isotope Dilution Mass Spectrometry†
}

\author{
Jung Suk Kim*, Young Shin Jeon, Yang-Soon Park, Yong Joon Park and Kyuseok Song
}

Nuclear Chemistry Research Division, Korea Atomic Energy Research Institute, Daeduk daero 989-111, Yuseong-gu, Daejeon 305-353, Republic of Korea

*Corresponding author: Fax: +82 42868 8148; E-mail: njskim1@kaeri.re.kr

\begin{abstract}
An isotope dilution mass spectrometric method (IDMS) has been used for the determination of caesium, neodymium, uranium and plutonium isotopes in pressurized water reactor (PWR) spent nuclear fuels irradiated in a power reactor. The method includes the determination of $\mathrm{Cs}, \mathrm{Nd}, \mathrm{U}, \mathrm{Pu}$ and their isotopes through thermal ionization isotope dilution mass spectrometric by using quadrupole spikes $\left({ }^{133} \mathrm{Cs},{ }^{150} \mathrm{Nd},{ }^{233} \mathrm{U}\right.$ and $\left.{ }^{242} \mathrm{Pu}\right)$. The measured atoms of the radioactive Cs isotopes $\left({ }^{134} \mathrm{Cs},{ }^{135} \mathrm{Cs}\right.$ and $\left.{ }^{137} \mathrm{Cs}\right)$ were corrected for the decay during and after irradiation. The total burnup (atom \% fission) determined from a measurement of the Cs isotope burnup monitors $\left({ }^{133} \mathrm{Cs}\right.$ and ${ }^{137} \mathrm{Cs}$ ) was compared with those by the $\mathrm{Nd}$ isotope burnup monitors $\left({ }^{148} \mathrm{Nd}\right.$ and $\left.{ }^{145} \mathrm{Nd}+{ }^{146} \mathrm{Nd}\right)$.
\end{abstract}

Key Words: IDMS, PWR spent fuel, Caesium, Neodymium, Uranium, Plutonium.

- - - - - - - - - - - - - - - - - - - - - - - - - - -

\section{INTRODUCTION}

The burnup of important fissile isotopes and the composition of an irradiated fuel depend on the nature of the fuel and on the conditions of an irradiation. A detailed knowledge of these quantities is useful for reactor work as well as for the effective utilization of a nuclear fuel. Various methods have been developed to measure a burnup both by non-destructive and destructive techniques. Destructive method, which is based on the determination of specific nuclides, e.g. U, Pu and ${ }^{148} \mathrm{Nd}$ (or ${ }^{137} \mathrm{Cs}$ ) by a chemical analysis of the heavy elements and a monitoring of the fission product, is widely used as a reference method to measure the burnup of a spent fuel ${ }^{1-3}$. The stable fission product method is almost independent of the irradiation history and as such it is capable of a high overall accuracy. Of the many stable nuclides formed in a fission, $\mathrm{Nd}$ satisfies most of the necessary requirements for a good burnup monitor ${ }^{1}$. All the isotopic compositions for the fission product $\mathrm{Cs}$ involving the stable ${ }^{133} \mathrm{Cs}$ and radioactive ${ }^{134} \mathrm{Cs}$, ${ }^{135} \mathrm{Cs}$ and ${ }^{137} \mathrm{Cs}$ can be measured using mass spectrometric techniques.

The aim of the present work is to determine simultaneously Cs, Nd, U, Pu and their isotopes for the samples from pressurized water reactor (PWR) fuels of $\mathrm{UO}_{2}$ type irradiated to a high burnup in power reactors and to determine the burnup using the measured results, so as to determine the respective validity of the methods. All experiments are described for the determination of isotope compositions of the fission products $(\mathrm{Cs}$ and $\mathrm{Nd}$ ) and the fissile elements ( $\mathrm{U}$ and $\mathrm{Pu}$ ) after their separation by the ion exchange separation techniques and also the determination of the elements in an irradiated fuel by the isotope dilution mass spectrometric method by using ${ }^{133} \mathrm{Cs}$, ${ }^{150} \mathrm{Nd},{ }^{233} \mathrm{U}$ and ${ }^{242} \mathrm{Pu}$ as spikes.

\section{EXPERIMENTAL}

Certified ${ }^{233} \mathrm{U}\left(99.470\right.$ atom \%) and ${ }^{150} \mathrm{Nd}(96.13$ atom \%) spikes were obtained from Oak Ridge National Laboratory. The spike solutions were prepared by dissolving the oxides in $8 \mathrm{M} \mathrm{HNO}_{3}-0.01 \mathrm{M} \mathrm{HF}$. Certified ${ }^{242} \mathrm{Pu}$ spike solution (99.9033 atom \%, IRMM-044) was obtained from the Institute for reference materials and measurements. The ${ }^{133} \mathrm{Cs}$ spike solution was obtained with monoisotopic standard solutions from Spex Industries Inc. The concentrations of the spike solutions of ${ }^{150} \mathrm{Nd}$ and ${ }^{233} \mathrm{U}$ were determined by calibrating them by isotope dilution mass spectrometry (IDMS) with a standard solution. The PWR nuclear fuels used in this work were irradiated to a high burnup in two power reactors (U-2 and U-3), with an enrichment of 4.2 and $4.5 \mathrm{w} / \mathrm{o}$, respectively and then cooled for 2 years for the post-irradiation analyses. The isotopic compositions of $\mathrm{Cs}, \mathrm{Nd}, \mathrm{U}$ and $\mathrm{Pu}$ separated from the fuel samples were determined by using a thermoionization mass spectrometer (TIMS) of the Finnigan MAT 262 type. 
An aliquot of the diluted fuel solution was placed in a capped vial and transferred from the shielded facility into a glove box by a pneumatic transfer system. Chemical separation was carried out for both the unspiked and the spiked sample solutions in the same experimental conditions in a glove box without any heavy shieldings. Two portions were subjected to a determination of the $\mathrm{Cs}, \mathrm{Nd}, \mathrm{U}$ and $\mathrm{Pu}$ isotopes in the sample with and without a spike addition followed by the sequential anion and cation exchange separation procedures detailed in Fig. 1.

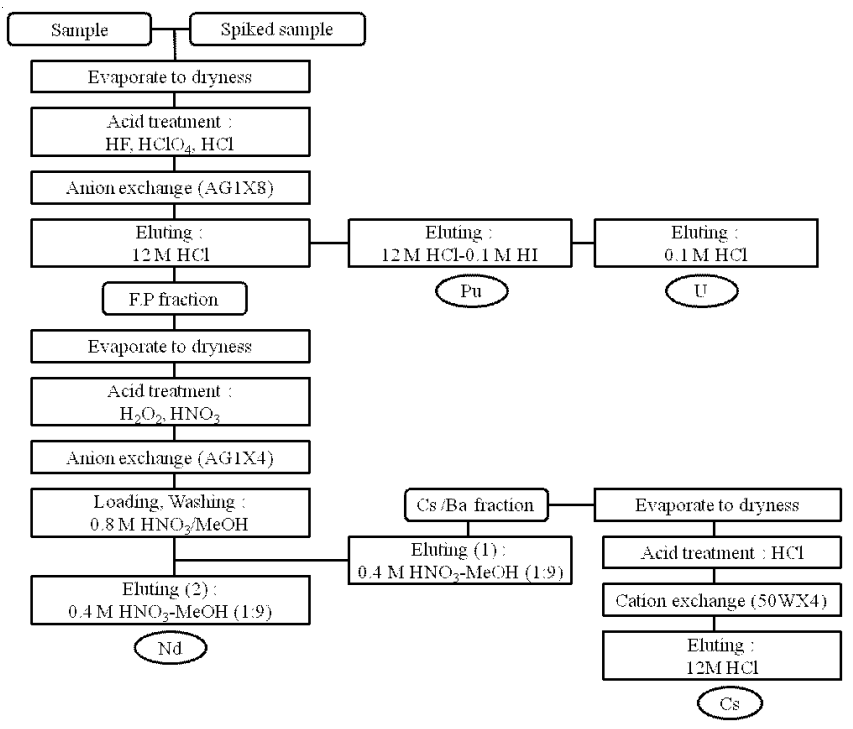

Fig. 1. Analytical scheme for $\mathrm{Cs}, \mathrm{Nd}, \mathrm{U}$ and $\mathrm{Pu}$ separation

\section{RESULTS AND DISCUSSION}

Determination of isotopic compositions: Each fractions of $\mathrm{Cs}, \mathrm{Nd}, \mathrm{U}$ and $\mathrm{Pu}$ isolated and concentrated, followed by the separation procedures shown in Fig. 1, in the range of $\mu \mathrm{g}$ to ng were loaded onto a triple rhenium filament and then the isotopic compositions in each fractions were measured by the thermal ionization mass spectrometer. The mass discrimination bias factor and the contribution of natural $\mathrm{Nd}$ for all the $\mathrm{Nd}$ isotopes measured was corrected in order to achieve a high accuracy for the isotopic composition and burnup measurement $^{1-3}$. Contributions of various isobars to the $\mathrm{Cs}$ and $\mathrm{Nd}$ fractions were identified by monitoring the mass peaks from 130 to 138 and from 140 to 150 , respectively (Table-1). The measured atoms of the radioactive $\mathrm{Cs}$ isotopes $\left({ }^{134} \mathrm{Cs},{ }^{135} \mathrm{Cs}\right.$ and ${ }^{137} \mathrm{Cs}$ ) were corrected for the decay during and after the irradiation according to the following equation ${ }^{4}$ :

\begin{tabular}{|c|c|c|}
\hline \multicolumn{3}{|c|}{$\begin{array}{l}\text { TABLE-1 } \\
\text { CONTRIBUTION OF OTHER ISOBARS FOR } \\
\text { FISSION PRODUCT Cs AND Nd ISOTOPES }\end{array}$} \\
\hline Isotope & Fission Products & Natural \\
\hline 133 & $\mathrm{Cs},{ }^{117} \mathrm{Sn}^{16} \mathrm{O}$ & $\mathrm{Cs},{ }^{117} \mathrm{Sn}^{16} \mathrm{O}$ \\
\hline 134 & $\mathrm{Cs}, \mathrm{Ba},{ }^{118} \mathrm{Sn}^{16} \mathrm{O}$ & $\mathrm{Ba},{ }^{118} \mathrm{Sn}^{16} \mathrm{O}$ \\
\hline 135 & $\mathrm{Cs}, \mathrm{Ba},{ }^{119} \mathrm{Sn}^{16} \mathrm{O}$ & $\mathrm{Ba},{ }^{119} \mathrm{Sn}^{16} \mathrm{O}$ \\
\hline 137 & $\mathrm{Cs}, \mathrm{Ba},{ }^{121} \mathrm{Sb}^{16} \mathrm{O}$ & $\mathrm{Ba},{ }^{121} \mathrm{Sb}^{16} \mathrm{O}$ \\
\hline 143 & $\mathrm{Nd}$ & $\mathrm{Nd}$ \\
\hline 144 & $\mathrm{Nd}, \mathrm{Ce},{ }^{128} \mathrm{Te}^{16} \mathrm{O}$ & $\mathrm{Nd}, \mathrm{Sm},{ }^{128} \mathrm{Te}^{16} \mathrm{O}$ \\
\hline 145 & $\mathrm{Nd}$ & $\mathrm{Nd}$ \\
\hline 146 & $\mathrm{Nd},{ }^{130} \mathrm{Te}^{16} \mathrm{O}$ & $\mathrm{Nd},{ }^{130} \mathrm{Ba}^{16} \mathrm{O},{ }^{130} \mathrm{Te}^{16} \mathrm{O}$ \\
\hline 148 & $\mathrm{Nd}, \mathrm{Sm}$ & $\mathrm{Nd}, \mathrm{Sm},{ }^{132} \mathrm{Ba}^{16} \mathrm{O}$ \\
\hline 150 & $\mathrm{Nd}, \mathrm{Sm},{ }^{134} \mathrm{Ba}^{16} \mathrm{O},{ }^{134} \mathrm{Cs}^{16} \mathrm{O}$ & $\mathrm{Nd}, \mathrm{Sm},{ }^{134} \mathrm{Ba}^{16} \mathrm{O}$ \\
\hline
\end{tabular}

$$
N^{\prime}=N \cdot \lambda t / e^{-\lambda t^{\prime}}\left(1-e^{-\lambda t}\right)
$$

where $\mathrm{N}^{\prime}$ : atoms of ${ }^{137} \mathrm{Cs}$ per $\mathrm{mL}$ corrected for the decay during and after irradiation; $\mathrm{N}:{ }^{137} \mathrm{Cs}$ atoms per $\mathrm{mL}$ at the time of measurement; $\lambda$ : ${ }^{137} \mathrm{Cs}$ decay constant; $t^{\prime}$ : elapsed time from the end of irradiation to measurement (s); t: irradiation time (s).

Tables 2 and 3 show the isotopic compositions of $U$ and $\mathrm{Pu}$ in the PWR fuel samples from a power reactor (U-3) measured by the TIMS, respectively. Data in the tables show that there is no isobaric effects from other elements. Table-4 shows the isotopic compositions of Cs in weight $\%$ for the PWR fuel samples from the power reactor (U-3) measured by a mass spectrometry. The measured values are in a good agreement with the calculated ones, which were obtained by correcting the elapsed time to measurement with the values by the ORIGEN code.

TABLE-2

ISOTOPIC COMPOSITIONS OF THE U SEPARATED FROM THE PWR SPENT FUEL SAMPLES

\begin{tabular}{cccc}
\hline & \multicolumn{3}{c}{ Atom (\%) } \\
\hline Isotope & $\mathrm{H}-1$ & $\mathrm{H}-2$ & $\mathrm{H}-3$ \\
\hline $\mathrm{U}-234$ & $0.020 \pm 0.002$ & $0.020 \pm 0.002$ & $0.021 \pm 0.002$ \\
$\mathrm{U}-235$ & $0.547 \pm 0.008$ & $0.640 \pm 0.004$ & $0.544 \pm 0.005$ \\
$\mathrm{U}-236$ & $0.698 \pm 0.004$ & $0.694 \pm 0.007$ & $0.695 \pm 0.003$ \\
$\mathrm{U}-238$ & $98.735 \pm 0.017$ & $98.645 \pm 0.012$ & $98.740 \pm 0.018$ \\
\hline
\end{tabular}

\begin{tabular}{cccc}
\multicolumn{4}{c}{ TABLE-3 } \\
$\begin{array}{cccc}\text { ISOTOPIC COMPOSITIONS OF THE Pu SEPARATED } \\
\text { FROM THE PWR SPENT FUEL SAMPLES }\end{array}$ \\
\hline \multicolumn{3}{c}{ Atom $(\%)$} \\
\hline Isotope & $\mathrm{H}-1$ & $\mathrm{H}-2$ & $\mathrm{H}-3$ \\
\hline $\mathrm{Pu}-238$ & $4.696 \pm 0.025$ & $7.089 \pm 0.020$ & $10.745 \pm 0.027$ \\
$\mathrm{Pu}-239$ & $45.733 \pm 0.020$ & $45.178 \pm 0.032$ & $43.214 \pm 0.032$ \\
$\mathrm{Pu}-240$ & $25.874 \pm 0.012$ & $24.953 \pm 0.020$ & $23.531 \pm 0.014$ \\
$\mathrm{Pu}-241$ & $13.234 \pm 0.010$ & $13.094 \pm 0.016$ & $12.624 \pm 0.008$ \\
$\mathrm{Pu}-242$ & $10.463 \pm 0.010$ & $9.685 \pm 0.040$ & $9.885 \pm 0.004$ \\
\hline
\end{tabular}

\begin{tabular}{|c|c|c|c|}
\hline \multicolumn{4}{|c|}{$\begin{array}{c}\text { TABLE-4 } \\
\text { ISOTOPIC COMPOSITIONS OF THE Cs SEPARATED } \\
\text { FROM THE PWR FUEL SAMPLES }\end{array}$} \\
\hline & \multicolumn{3}{|c|}{ Weight (\%) } \\
\hline Isotope & S-1 & S-2 & $\mathrm{S}-3$ \\
\hline Cs-133 & $40.2877(40.4772)$ & $40.4569(40.4538)$ & $40.4538(41.2558)$ \\
\hline Cs-134 & 1.7534 (1.6574) & $1.6527(1.3717)$ & $1.3717(1.3380)$ \\
\hline Cs-135 & $13.2637(13.2822)$ & $13.3017(15.9402)$ & $15.9402(14.5595$ \\
\hline Cs-137 & $44.6952(44.5832)$ & $44.5887(42.2343)$ & $42.2343(42.8467)$ \\
\hline
\end{tabular}

After the mass spectrometric measurement of each isolated portion from the spiked and unspiked sample solutions, the concentrations of $\mathrm{Cs}, \mathrm{Nd}, \mathrm{U}$ and $\mathrm{Pu}$ in the sample solutions were determined by using isotope dilution method. For example, the content of $\mathrm{Cs}$ in a sample solution can be calculated as follows:

$\mathrm{Cn}=\mathrm{Ca} \cdot(\mathrm{Ga} / \mathrm{Gn}) \cdot(\mathrm{Mn} / \mathrm{Ma}) \cdot[(\mathrm{Ra}-\mathrm{Rm}) /(\mathrm{Rm}-\mathrm{Rn})] \cdot(\mathrm{Nn} \mathrm{Ri} / \mathrm{La} \mathrm{Ri})$ where $\mathrm{Cn}$ : concentration of $\mathrm{Cs}$ in sample solution $(\mu \mathrm{g}-\mathrm{Cs} / \mathrm{mL})$; $\mathrm{Ca}$ : concentration of $\mathrm{Cs}$ in spike solution $(\mu \mathrm{g}-\mathrm{Cs} / \mathrm{mL})$; $\mathrm{Gn}$ : volume of sample solution taken $(\mathrm{mL})$; Ga: volume of spike solution taken $(\mathrm{mL})$; Mn: mean atomic weight of Cs in sample; Ma: mean atomic weight of Cs in spike; Ra: ratio of two basic isotopes in spike $\left({ }^{137} \mathrm{Cs} /{ }^{133} \mathrm{Cs}\right)$; Rm: ratio of two basic isotopes 
in mixture $\left({ }^{137} \mathrm{Cs} /{ }^{133} \mathrm{Cs}\right) ; \mathrm{Rn}$ : ratio of two basic isotopes in sample $\left({ }^{137} \mathrm{Cs} /{ }^{133} \mathrm{Cs}\right)$; $\Sigma$ s Ri: sum of ratios of total isotopes for a basic isotope in sample; $\Sigma \mathrm{t} \mathrm{Ri}$ : sum of ratios of total isotopes for a basic isotope in spike.

Table- 5 shows the content ratios calculated from the quantities of $\mathrm{U}$ and $\mathrm{Pu}$ in the PWR fuel samples determined by IDMS. The results obtained by IDMS were in the range of the values calculated by ORIGEN code for the fuel rod. Tables 6 and 7 show the quantities of $\mathrm{Cs}$ and $\mathrm{Nd}$ and their isotopes in the PWR fuel samples from the power reactor (U-2) determined by IDMS. Mass spectrometric isotope dilution analysis of ${ }^{137} \mathrm{Cs}$ with ${ }^{133} \mathrm{Cs}$ as an isotopic diluent would overcome the ${ }^{134} \mathrm{Cs}$ interference for a counting by the $\gamma$-spectrometric method.

\begin{tabular}{|c|c|c|c|}
\hline \multicolumn{4}{|c|}{$\begin{array}{c}\text { TABLE-5 } \\
\text { CONTENT RATIOS Pu TO U FOR THE } \\
\text { PWR SPENT FUEL SAMPLES }\end{array}$} \\
\hline Ratio & $\mathrm{H}-1$ & H-2 & H-3 \\
\hline$\% \mathrm{Pu} / \mathrm{U}$ & 1.287 & 1.342 & 1.409 \\
\hline \multicolumn{4}{|c|}{$\begin{array}{c}\text { TABLE-6 } \\
\text { QUANTITIES OF Cs AND ITS ISOTOPES IN THE PWR } \\
\text { FUEL SAMPLES DETERMINED BY ISOTOPE } \\
\text { DILUTION MASS SPECTROMETRY }\end{array}$} \\
\hline & & $\mu \mathrm{g} / \mathrm{mL}$ & \\
\hline Isotope & S-1 & S-2 & S-3 \\
\hline Cs-133 & 0.5388 & 0.4401 & 0.4726 \\
\hline Cs-134 & 0.0235 & 0.0184 & 0.0160 \\
\hline Cs-135 & 0.1774 & 0.1522 & 0.1862 \\
\hline Cs-137 & 0.5978 & 0.4930 & 0.4934 \\
\hline Total & 1.3375 & 1.1037 & 1.1682 \\
\hline
\end{tabular}

TABLE-7

QUANTITIES OF Nd AND ITS ISOTOPES IN THE PWR FUEL SAMPLES DETERMINED BY ISOTOPE DILUTION MASS SPECTROMETRY

\begin{tabular}{cccc}
\hline & \multicolumn{3}{c}{$\mu \mathrm{g} / \mathrm{mL}$} \\
\hline Isotope & $\mathrm{S}-1$ & $\mathrm{~S}-2$ & $\mathrm{~S}-3$ \\
\hline Nd-143 & 0.2887 & 0.2531 & 0.3207 \\
Nd-144 & 0.7052 & 0.5931 & 0.5846 \\
Nd-145 & 0.2939 & 0.2506 & 0.2806 \\
Nd-146 & 0.3619 & 0.3085 & 0.3125 \\
Nd-148 & 0.1821 & 0.1558 & 0.1624 \\
Nd-150 & 0.0883 & 0.0762 & 0.0783 \\
\hline Total & 1.9201 & 1.6373 & 1.7391 \\
\hline
\end{tabular}

Determination of the total burnup: Among the fission products, stable ${ }^{148} \mathrm{Nd}$ or radioactive ${ }^{137} \mathrm{Cs}$ was widely used as a monitor to estimate the burnup of a spent fuel by destructive techniques ${ }^{1,4,5}$. A different monitor such as ${ }^{145} \mathrm{Nd}+{ }^{146} \mathrm{Nd}$ can be used to estimate the burnup, because the sum of ${ }^{145} \mathrm{Nd}$ and ${ }^{146} \mathrm{Nd}$ appears to be invariant to the neutron flux and fluence ${ }^{6}$. Table- 8 shows the total burnup in atom $\%$ fission determined by the ${ }^{148} \mathrm{Nd}$ and ${ }^{145} \mathrm{Nd}+{ }^{146} \mathrm{Nd}$ monitor methods, together those calculated by the ${ }^{133} \mathrm{Cs}$ and ${ }^{137} \mathrm{Cs}$ monitor methods for the PWR fuel samples. When comparing the total burnup values obtained by ${ }^{148} \mathrm{Nd}$ and ${ }^{145} \mathrm{Nd}+{ }^{146} \mathrm{Nd}$ monitor methods, both results are in a good agreement with each other within a deviation less than $3 \%$. However, when comparing the total burnup values obtained by the ${ }^{148} \mathrm{Nd}$ monitor method with those by the ${ }^{133} \mathrm{Cs}$ and ${ }^{137} \mathrm{Cs}$ monitor methods, the total burnup values obtained by the Cs monitor methods for $\mathrm{S}-1$ which is relatively higher burnup compared with S-3 sample shows a maximum $8 \%$ higher value than those by ${ }^{148} \mathrm{Nd}$ monitor method. However, for S-3 sample which is relatively lower burnup, the total burnup values obtained by the Cs monitor methods are in a good agreement with those by ${ }^{148} \mathrm{Nd}$ monitor method within less than $1 \%$. It is assumed that the errors from the measured atoms of radioactive $\mathrm{Cs}$ isotopes is attributable to an uncertainty in the physical constants and an inaccurate knowledge of the irradiation history in a reactor.

TABLE-8

TOTAL BURNUP IN ATOM\% FISSION DETERMINED BY THE Cs AND Nd ISOTOPE MONITOR METHODS FOR THE PWR FUEL SAMPLES

\begin{tabular}{ccccc}
\hline & & \multicolumn{3}{c}{ Atom \% fission } \\
\hline & Nd-148 & Nd- $(145+146)$ & Cs-133 & Cs-137 \\
\hline S-1 & $6.375 \pm 0.151$ & $6.196 \pm 0.147$ & $6.824 \pm 0.162$ & $6.910 \pm 0.164$ \\
S-2 & $6.401 \pm 0.152$ & $6.404 \pm 0.152$ & $6.503 \pm 0.154$ & $6.707 \pm 0.159$ \\
S-3 & $5.152 \pm 0.122$ & $5.145 \pm 0.122$ & $5.161 \pm 0.122$ & $5.207 \pm 0.123$ \\
\hline
\end{tabular}

\section{Conclusion}

The quantities of $\mathrm{Cs}, \mathrm{Nd}, \mathrm{U}$ and $\mathrm{Pu}$ and their isotopes in the PWR fuel samples can be simultaneously determined by the isotope dilution mass spectrometric method by using the quadruple spikes. The number of Cs atoms and their isotopic compositions obtained by the IDMS technique can be used to calibrate those by the radiometric method. Considering of ${ }^{145} \mathrm{Nd}$ $+{ }^{146} \mathrm{Nd},{ }^{133} \mathrm{Cs}$ and ${ }^{137} \mathrm{Cs}$ isotopes as a burnup monitor primarily provides an advantage for the confirmation of the burnup value obtained by using ${ }^{148} \mathrm{Nd}$ monitor.

\section{REFERENCES}

1. Standard Test Method for Atom Percent Fission in Uranium and Plutonium Fuel (Neodymium-148 Method). Annual Book of ASTM Standards 12.02. E321-96 (2005).

2. J.S. Kim, Y.S. Jeon, K.S. Choi, B.C. Song, S.H. Han and W.H. Kim, J. Korean Nucl. Soc., 33, 375 (2001).

3. J.S. Kim, Y.S. Jeon, S.D. Park, B.C. Song, S.H. Han and J.G. Kim, Nucl. Eng. Technol., 38, 301 (2006).

4. Standard Test Method for Atom Percent Fission in Uranium Fuel (Radiochemical Method. Annual Book of ASTM Standards 12.02. E219-80 (1987).

5. J. Krtil, F. Sus and A. Hermann, Radiochem. Radioanal. Lett., 48, 209 (1981).

6. W.H. Walker, Fission Product Data for Thermal Reactors. Atomic Energy of Canada Limited Report AECL-3037. Part 1 and 2 (1972). 